\title{
Certifying leaders? high-quality management practices and healthy organisations: an ISO-9000 based standardisation approach
}

\author{
Diego MONTANO ${ }^{1}$ \\ ${ }^{1}$ Institute for Medical Psychology and Sociology, University of Goettingen, Germany \\ Received September 17, 2015 and accepted January 28, 2016 \\ Published online in J-STAGE February 10, 2016
}

\begin{abstract}
The present study proposes a set of quality requirements to management practices by taking into account the empirical evidence on their potential effects on health, the systemic nature of social organisations, and the current conceptualisations of management functions within the framework of comprehensive quality management systems. Systematic reviews and meta-analyses focusing on the associations between leadership and/or supervision and health in occupational settings are evaluated, and the core elements of an ISO 9001 standardisation approach are presented. Six major occupational health requirements to high-quality management practices are identified pertaining to communication processes, organisational justice, role clarity, decision making, social influence processes and management support. It is concluded that the quality of management practices may be improved by developing a quality management system of management practices that ensures not only conformity to product but also to occupational safety and health requirements. Further research may evaluate the practicability of the proposed approach.
\end{abstract}

Key words: ISO 9000, Management practices, Leadership, Occupational health, Quality management system

\section{Introduction}

Management practices, as a general concept including not only leadership in terms of social influence processes ${ }^{1)}$ but also the direction and control of organisations ${ }^{2)}$, have been identified in occupational health research as a key organisational factor involved in the causal pathways linking the work environment and several health-related outcomes of the organisation's members. In spite of the uncertainty regarding the specific causal mechanisms determining those pathways, several systematic reviews and meta-analyses, especially in the leadership and epidemiology literature, have reported consistent associations

To whom correspondence should be addressed.

E-mail: diego.montano@med.uni-goettingen.de

(C)2016 National Institute of Occupational Safety and Health between leadership practices and important health-related outcomes such as affective symptoms, burnout, stress, well-being $^{3-5)}$, musculoskeletal symptoms ${ }^{6}$, , job satisfaction $^{7,8)}$, and organisational commitment ${ }^{9,10)}$. However, research on management practices is usually restricted to the investigation of the most efficient ways of attaining organisational goals and sustaining organisational functions ${ }^{11,12)}$, without taking into account that the manner how management practices are enacted has important effects on members' physical and mental health. In fact, management research has produced an enormous body of evidence concerning strategic management, human resources, attainment of organisational goals, the design of work processes, and the enhancement of individual and organisational performance, among others ${ }^{13-15}$. On the contrary, the literature on theoretical and practical approaches to health-oriented management practices is much more limited. Some 
Table 1. Standardisation approaches for compliance with occupational safety and health (OSH) regulations and guidelines

\begin{tabular}{|c|c|c|}
\hline & Advantages & Disadvantages \\
\hline $\begin{array}{l}\text { Traditional approach: com- } \\
\text { pliance with OSH statutory } \\
\text { requirements }\end{array}$ & $\begin{array}{l}\text { - Compliance to requirements only - no further efforts } \\
\text { expected } \\
\text { - Simple evaluation of degree of compliance (e.g. check } \\
\text { lists, questionnaires) } \\
\text { - Very low costs for a given minimum level of compli- } \\
\text { ance }\end{array}$ & $\begin{array}{l}\text { - Predominantly ad-hoc solutions } \\
\text { - Increasing operative costs in the long run due to defi- } \\
\text { cient health prevention strategies } \\
\text { - No incentives for improvement } \\
\text { - Superficial evaluation may lead to persistent occupa- } \\
\text { tional health risks }\end{array}$ \\
\hline $\begin{array}{l}\text { Process-based approach: inte- } \\
\text { gration of OSH regulation } \\
\text { in the internal processes of } \\
\text { organisations }\end{array}$ & $\begin{array}{l}\text { - Compliance to requirements is the result of internal } \\
\text { processes } \\
\text { - Integration of OSH in existing management systems } \\
\text { - Continual improvement of OSH-related output beyond } \\
\text { legal requirements } \\
\text { - Systematic assessment of risks at their origin in inter- } \\
\text { nal processes } \\
\text { - Risk reduction measures involve whole processes and } \\
\text { their interactions }\end{array}$ & $\begin{array}{l}\text { - Higher costs of implementation during early stages } \\
\text { due to the adaptation and change of existing internal } \\
\text { processes } \\
\text { - Continual measurement, analysis and evaluation } \\
\text { may be unfeasible for small organisations with lower } \\
\text { resources }\end{array}$ \\
\hline
\end{tabular}

recent theoretical and practical approaches in this direction are based on the so-called "health-oriented leadership behaviours" such as leader behavioural integrity regarding safety and work-related injuries ${ }^{16)}$, leaders' heath-specific orientation towards followers and followers' health-specific behaviour towards themselves ${ }^{17)}$.

Although these approaches incorporate leadership as an important factor promoting health and reducing workrelated symptoms and health risks, they are not adequate for defining occupational health criteria regarding the quality of management practices. This inadequacy is due to at least three major limitations. First, it is proposed that leader behaviours may be used as an instrument for complying with occupational health regulations and goals. Thus, the fact that management (and/or leadership) practices per se are an occupational health factor is not addressed. Second, leader health-oriented behaviours are defined at the individual and not at the organisational level. Hence, the systemic nature of organisations is not properly considered. And third, the sustainability and impact of healthy management (and/or leadership) practices is not guaranteed. On the contrary, focusing on leader behaviour may increase the vulnerability and instability of management practices by relying too much on individual supervisors and (line) managers.

The recent guidelines called "Workplace health: management practices" released in 2015 by the National Institute of Health and Care Excellence (NICE) in the United Kingdom ${ }^{18)}$ are a remarkable advance towards a truly organisational-based approach in occupational health. The NICE guidelines directly address the organisational culture and context, and the role of line managers regarding the health and well-being of employees. On the basis of extensive literature overviews, the guidelines state 11 general recommendations including organisational commitment to health, safe physical work environments, mental well-being, participation, senior leadership, job design, among others. Nonetheless, the guidelines lack a general conceptual framework linking the type and scope of the different recommendations. This results in a rather heterogeneous set of recommendations mixing health outcomes (e.g. mental well-being), strictly managerial activities (e.g. employee participation in organisational decisions), and working conditions (e.g. physical environment) with individual behaviours (e.g. leadership styles).

In contrast to the individual-level and the NICE guidelines approach, modern occupational safety and health (OSH) regulations and guidelines such as the EU Directive 89/391/EEC and the ILO-OSH Health Management System ${ }^{19)}$ are grounded on systemic process-oriented management principles. The major aim of adopting these principles is to facilitate the design of healthy work environments and procedures that fit into the routines and procedures of organisations ${ }^{20)}$. A process-oriented approach in occupational health management has several advantages including the elimination or reduction of the causes leading to work-related symptoms or diseases ${ }^{21)}$, a lower cost of implementation, maintenance and improvement of healthy work environments due to its compatibility with comprehensive management systems ${ }^{19}$, and a higher resilience in face of external or internal changes affecting the organisation (see Table 1). Moreover, in comparison with the NICE guidelines, a process-oriented approach offers a general principle of action and coordination of activities that conceptually separates outcomes and managerial activities from individual behaviours. In addition, a process-based 


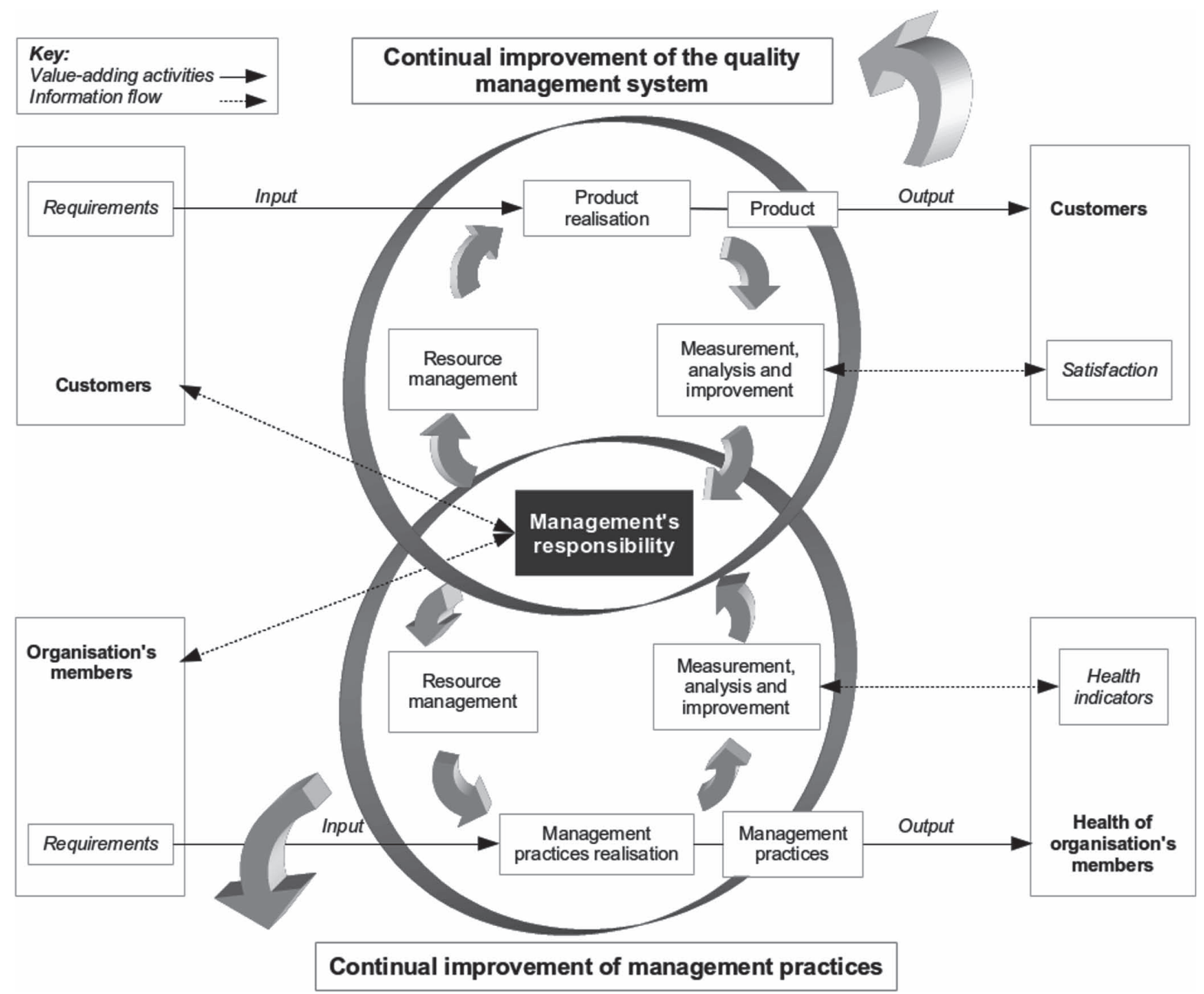

Fig. 1. Process-based quality management system for continual improvement on the basis of DIN EN ISO 9000:2005.

approach facilitates the integration of new occupational health requirements in different internal processes of the organisation.

Consequently, the present paper proposes a set of specific quality requirements of management practices that takes into account (1) the empirical evidence of the potential effects of management practices on health, (2) the systemic nature of social organisations, and (3) current conceptualisations of management functions within the framework of comprehensive quality management systems. The main objective is thus to propose a standardisation approach which combines the results of occupational health research on management (and leadership) practices, and the commitment demanded from management to attain organisational goals.

\section{Theoretical Background}

The ISO 9000 standardisation approach in occupational safety and health

The ISO 9000 standard is a process-based quality management system, i.e. a standard that specifies a set of concepts and procedures by means of which an organisation should direct and control its processes with regard to quality requirements. Within the ISO 9000 approach, the concept of process refers to "a set of interrelated or interacting activities which transform inputs into outputs"2). Processes constitute the core elements of the quality management system since they may take a set of quality requirements as inputs and produce a set of outputs satisfying those initial requirements (see upper loop in Fig. 1). Moreover, processes may be interconnected to establish a time-dependent feedback system of continual improvement that enhances the fulfilment of quality requirements of products or services. 
The adaptation of a process-based quality management system such as ISO 9000 to occupational health (OSH) requirements may represent a more suitable alternative for improving compliance. This can be observed if we compare the traditional approach that has been used to enhance compliance with OSH regulations with a process-based one. In the traditional approach, organisations are simply expected to comply with OSH statutory requirements only. On the contrary, a process-based approach integrates OSH regulation in the internal processes of the organisation so that compliance thus becomes the result of internal processes leading to conformity with specific quality requirements of occupational health.

Even though under certain circumstances both standardisation approaches may lead to similar results concerning the health states of the organisation's members, they substantially differ regarding the role of occupational health requirements and members' health in the system processes. Whereas in the first approach occupational health requirements correspond to disturbances of organisational pro$\operatorname{cesses}^{22)}$, i.e. the employers' obligation to comply with external requirements outside the scope of organisational functions, in the second approach they are essential components of input. Moreover, since the first approach does not specify the role of members' health in the system, it seems that health is not an integral part of organisational processes. This is contrasted in the second approach by interpreting health as an organisational output.

Since the aim of the present paper is to propose a standardisation of management practices combining occupational health requirements and management's commitment to organisational goals, a process-based approach seems to be much more suitable for this purpose. A comparison of the advantages and disadvantages of each approach (see Table 1) suggests that a process-based management system is superior not only regarding internalisation of OSH regulations, but also the improvement of occupational health practices. In view of the fact that the ISO 9000 family of standards is by far the most widely spread quality management system across industrial sectors, the standardisation of management practices presented in this study follows the ISO 9000 principles and recommendations for quality management.

However, before proceeding to the description of the proposed standardisation of management practices, it is necessary to specify some basic concepts that will be used in later sections. Management designates the "coordinated activities to direct and control an organization"2). Even though the concept of leadership is commonly understood as the social influence processes taken place between leaders and followers ${ }^{1-14)}$, it is clear that from a functional perspective leadership is enacted to coordinate activities, and to direct and control the organisation. Thus, it is convenient for the purposes of standardisation to subsume these social influence processes in the general concept of management. Practices designate overt and measurable behaviours and institutionalised norms such as instructions, prescriptions, proscriptions and sanctions enacted by the members of the organisation ${ }^{23,24)}$. Quality is defined as the degree to which a "set of inherent characteristics fulfils requirements"2). In this paper, requirements correspond to occupational health needs or expectations, implied or obligatory, concerning management practices. Management system defines a system to establish policy and objectives and to achieve those objectives $^{2)}$.

\section{Empirical evidence on management practices concerning health and organisational outcomes}

In order to capture fundamental characteristics of management practices affecting health and organisational outcomes, systematic reviews and meta-analyses focusing on the associations between leadership and/or supervision and health in occupational settings were identified by screening in the following databases: PubMed (PMC), Scopus and PsycArticles. The queries were supplemented by a manual search in leading journals of occupational health, management sciences, and organisational psychology (see Annex 1). The search strings for each database had the general form "Leadership/Management AND Health/ Organisational outcomes AND Occupational setting", and are reported in Annex 1.

A total of 19 systematic reviews and meta-analyses investigating the relationship between management practices (leadership and/or supervision), health and organisational outcomes were identified. Most studies were performed in the context of leadership research in organisational psychology, and focus on the following management practices and/or leadership styles and behaviours. Transformational leadership refers to an inspiring, charismatic, motivating and visionary leadership style ${ }^{25,26)}$. Transactional leadership represents the exchanges resulting from a relationship of mutual dependence between leaders and followers ${ }^{25}$. Leader-member exchange refers to the observation that leaders develop differentiated relationships with their followers ${ }^{27}$. It is expected that the quality of the leader-member exchange affects several health and organisational outcomes. Relations-oriented leader behaviours include several facets including concern for 
Table 2. Evidence on management practices affecting health and organisational outcomes

\begin{tabular}{|c|c|c|c|c|}
\hline Study & $\begin{array}{c}\text { Management/ } \\
\text { Leadership practices }\end{array}$ & Health outcomes & Organisational outcomes & $\begin{array}{c}\text { Implications for management practice } \\
\text { requirements }\end{array}$ \\
\hline $\begin{array}{l}\text { Chiaburu et } \\
\text { al. }^{43)}\end{array}$ & $\begin{array}{l}\text { Leader-member exchange, } \\
\text { empowering leadership, } \\
\text { leader fairness, openness } \\
\text { and consideration }\end{array}$ & & $\begin{array}{l}\text { Increased change-oriented citi- } \\
\text { zenship behaviour }\end{array}$ & $\begin{array}{l}\text { Organisational resilience may be } \\
\text { improved by encouraging participation } \\
\text { in decision making and suggestions for } \\
\text { improvements, proving feedback, reward- } \\
\text { ing employees for initiatives, and enhanc- } \\
\text { ing creative performance and proactive } \\
\text { behaviour }\end{array}$ \\
\hline
\end{tabular}

Chiaburu et Contingent reward, leader-

$a l{ }^{44)} \quad$ member exchange, and transformational leadership

Colquitt et Organisational justice $a .^{45)}$

Increased positive affect, decreased negative affect

organisational performance, (atizenship behaviour and less counterproductive work behaviour

Dulebohn et Leader-member exchange $a l^{46)}$

s

Affective commitment, general job satisfaction, satisfaction with supervisor and pay
Proactive and prosocial behaviours, task performance

Leaders may utilise different leadership styles for enhancing followers' proactivity

Management practices require the formulation and documentation of clear rules concerning procedural, distributive, interpersonal and informational justice issues

Reduced turnover intentions, Management practices encourage high increased job performance, levels of reciprocity, respect and support increased organisational com- with all work units. Segregation of in- and mitment, more positive percep- out-groups should be avoided tion of organisational justice and empowerment, and less role ambiguity and conflict

\section{Gerstner and Leader-member exchange \\ Higher overall satisfac-} Day $^{9)}$ tion

Higher objective performance increased organisational commitment, and less turnover intentions

Management practices encourage high levels of reciprocity, respect and support with all work units. Segregation of in- and out-groups should be avoided

Gregersen et Several leader behaviours For positive behaviours: Turnover, sick leave, presen-

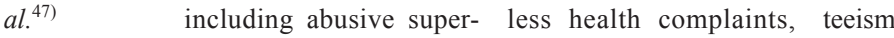
vision, conflict solving burnout and affective skills, supervisor support, symptoms, and increased relations- and task-ori- job satisfaction ented behaviour and transformational leadership

Hastings et Governance mechanisms Increased job satisfaction, Decreased turnover

$a l^{48)} \quad$ in health care increased empowerment

Ilies et al. ${ }^{49)} \quad$ Leader-member exchange
increased empowerment

Organisational citizenship
behaviours
Higher task performance and organisational citizenship behaviour, and fewer turnover intentions

Judge and Transformational leader- Higher job satisfaction Increased group or organisation Piccolo $^{7}$ ship, transactional leadership, laissez-faire leadership and motivation for transformational and transactional leadership; less job satisfaction and motivation for laissez-faire leadership performance and leader effectiveness for transformational and transactional leadership; less leader effectiveness for laissez-faire leadership performance and leader effec-
Judge et al. ${ }^{8)}$ Leader consideration and Higher job satisfaction Increased group or organisation leader initiating structure and motivation
Management practices have important effects on several outcomes related to mental and physical health. Organisations should minimise risks and enhance resources at the organisational and interpersonal level

Clear management goals and communication, strong leadership

High-quality relationships between leaders and followers may motivate organisation's member to engage in behaviours beyond their prescribed roles

Contingent reward behaviours should correspond to perceived procedural and distributive justice

Social influence may be enhanced by setting clear goals, conveying a common vision, and encouraging creativity. Management practices should be based on transparent expectations of duties and rewards. Supervisors and (line) managers should actively lead followers and take the initiative tiveness

Management practices should enforce respect and concern for all members of the organisation. Roles, goals, communication channels, and expectations should be explicitly given 
Table 2. Continued

\begin{tabular}{|c|c|c|c|c|}
\hline Study & $\begin{array}{c}\text { Management/ } \\
\text { Leadership practices }\end{array}$ & Health outcomes & Organisational outcomes & $\begin{array}{l}\text { Implications for management practice } \\
\text { requirements }\end{array}$ \\
\hline $\begin{array}{l}\text { Kuoppala et } \\
a l^{3)}\end{array}$ & $\begin{array}{l}\text { Relations-oriented leader- } \\
\text { ship, leader support and } \\
\text { transformational leader- } \\
\text { ship }\end{array}$ & $\begin{array}{l}\text { Increased job satisfaction } \\
\text { and well-being }\end{array}$ & $\begin{array}{l}\text { Higher job performance for } \\
\text { leader support }\end{array}$ & $\begin{array}{l}\text { Management practices have important } \\
\text { effects on several outcomes related to } \\
\text { mental and physical health. Organisa- } \\
\text { tions should minimise risks and enhance } \\
\text { resources at the organisational and inter- } \\
\text { personal level }\end{array}$ \\
\hline $\begin{array}{l}\mathrm{Ng} \text { and } \\
\text { Feldman }\end{array}$ & Ethical leadership & $\begin{array}{l}\text { Higher job motivation } \\
\text { and satisfaction, reduced } \\
\text { job strains }\end{array}$ & $\begin{array}{l}\text { Higher task performance, } \\
\text { increased citizenship behaviour } \\
\text { and affective organisational } \\
\text { commitment, less counterpro- } \\
\text { ductive work behaviour, less } \\
\text { turnover intentions }\end{array}$ & $\begin{array}{l}\text { Management practices should foster con- } \\
\text { formity to norms, appropriate conduct } \\
\text { through personal actions and interper- } \\
\text { sonal relationships, trustworthiness, fair- } \\
\text { ness, and prudency }\end{array}$ \\
\hline
\end{tabular}

\begin{tabular}{ll}
\hline Nyberg et & Relations- and task-ori- \\
$a l^{52)}$ & ented leadership, transfor- \\
& mational and transactional \\
& leadership
\end{tabular}

Podsakoff et Contingent and non-con$a l .{ }^{53)} \quad$ tingent reward and punishment leader behaviour

Rockstuhl et Leader-member exchange Higher job satisfaction
$a l .{ }^{54)}$

Increased affective commitment, continuance commitment, perceived organisational support and higher performance, and less turnover intentions for contingent reward behaviour of leaders. The opposite associations holds for non-contingent punishment behaviour

Increased task performance,
organisational commitment behaviour, higher levels of perceived justice and affective commitment

\begin{tabular}{llll}
\hline Schyns and & $\begin{array}{l}\text { Destructive leadership Higher levels of nega- } \\
\text { Schilling }\end{array}$ & $\begin{array}{l}\text { Higher turnover intentions, } \\
\text { behaviours (including tive affectivity, stress } \\
\text { abusive supervision, boss- }\end{array}$ \\
& $\begin{array}{l}\text { and lower levels of well- } \\
\text { ingegative leadership, and decreased levels of } \\
\text { among others) }\end{array}$ & $\begin{array}{l}\text { being and individual per- } \\
\text { formance }\end{array}$ & $\begin{array}{l}\text { perceived justice and less over- } \\
\text { all commitment }\end{array}$ \\
\hline Seibert et & Perceived high-quality & Increased psychological & Reduced turnover intentions, \\
al. ${ }^{55}$ & management practices, empowerment, improved & increased organisational com- \\
& leader support, posi- job satisfaction, reduced & mitment \\
& tive communication with strain & \\
& supervisor, participative & \\
and transformational lead- & & \\
& ership, and trust in leader &
\end{tabular}

Health promoting leadership behaviour includes showing consideration toward subordinates, initiating structure, allowing work control, empowering followers, inspiring and stimulating followers

The effectiveness of reward and punishment leader behaviour depends on whether they are enacted contingently upon employee performance. Moreover, these leader behaviours strongly depend on employees' perception of justice and role ambiguity. Management practices should clearly communicate the procedures related to contingent rewards and punishments

Management practices should foster high quality relationships between leaders and followers by taking into account specificities or organisational and societal culture

All forms of destructive leadership (aggression, mobbing, mocking) should be strictly avoided and/or sanctioned

Perceptions of the quality of management practices should inform the formulation of management practices guidelines regarding central management aspects such as incentives, organisational empowerment, participatory goal setting and decision making, justice/fairness procedures, and organisational learning practices

Management practices have important effects on several outcomes related to mental and physical health. Organisations should minimise risks and enhance resources at the organisational and interpersonal level 
the problems of subordinates, participative leadership, and conflict-solving abilities, among others ${ }^{14)}$. Task-oriented leader behaviours include facets such as a well-defined assignment of tasks to subordinates, an emphasis on the achievement of groups' goals, and a focus on production and organisational deadlines ${ }^{1)}$. Leader and organisational support denote the beliefs that supervisors, (line) managers (or the perceived organisation) assist followers for the successful completion of job tasks and assignments, and provide socio-emotional support ${ }^{28,29}$. The direction of associations between management and/or leadership practices, health and organisational outcomes, and their implications for occupational health requirements concerning management practices are reported in Table 2 .

\section{Occupational health requirements concerning manage- ment practices}

The results summarised in Table 2 strongly support the notion that specific management practices may have large impacts on a large array of both health-related and organisational outcomes. Instances of these practices include a high-quality of social interaction between leaders and followers, relations- and task-oriented leader behaviours, transparent rules concerning organisational justice (e.g. procedural, distributive, and interactional justice), appropriate internal and external communication channels, and a motivating, inspiring and trustful leadership. Since these results are based on systematic reviews and meta-analyses covering hundreds of studies and samples in different countries and occupational settings, they represent a solid basis for establishing major occupational health requirements to management practices. For standardisation purposes, however, it is necessary to formulate very specific characteristics of management practices which can be mapped to a series of instruments measuring the degree of conformity to a concise set of requirements.

In the present study these specific characteristics of management practices are identified with the help of organisational theory by considering the following wellknown structuring attributes of organisations ${ }^{30,31)}$ :

1. Specialisation (e.g. the division of labour and departmentalisation processes)

2. Coordination of organisational activities (e.g. definition of communication strategies, assignment of tasks, social influence processes, definition of goals)

3. Authority (e.g. unity of command, span of control, issuing of instructions, power relationships)

4. Decision making (e.g. participation, delegation, legal representation and contractual power)
5. Degree of formalisation (i.e. documentation of procedures and rules).

These structuring attributes of organisations imply that a series of interrelated management activities are needed in order to ensure the continuity and existence of the organisation as a whole. For instance, the division of labour and the departmentalisation of the organisation result from previous decision making processes involving the definition of goals, assignment of tasks, communication of results, and delegation of authority. Moreover, the results reported in Table 2 capture relevant management practices which can be mapped into the main structuring attributes of organisations mentioned above. On the basis of this mapping exercise, a set of central characteristics of management practices, their dimensions, and the occupational health requirements concerning management practices are proposed in the present study. In addition, some examples of variables and information sources (organisational vs. members' assessments) for each characteristic of management practices are provided (see Table 3 ).

Communication is a central characteristic of management processes satisfying core organisational functions such as sufficient information supply across work units, the coordination of work tasks, and the successful completion of problem solving tasks and decision making. Thus, high-quality communication practices can be defined by assessing whether management practices ensure that the information needed for accomplishing those functions is actually being exchanged. Organisational justice includes the socio-normative fundamentals of organisational procedures, allocation-related outcomes such as performance appraisal, compensation schemes, and task assignments, and interactional aspects concerning fair treatment of recipients ${ }^{32,33)}$. The corresponding quality requirements regarding organisational justice demand clearly defined rules of procedures, allocation and interpersonal treatment. Role clarity concerns the degree of consistency (or conflict) of the work roles, and the subjective experiences of the organisation's members concerning those roles ${ }^{34-36)}$. Accordingly, a clear definition of roles, tasks and responsibilities expected from the organisation's members, and a consistent formulation of job roles represent appropriate quality requirements of management practices.

Decision making refers to the extent to which each member of the organisation is actively involved in the definition and design of relevant organisational processes such as the formulation of work tasks, the implementation of changes or suggestions, the use of specific work methods, and the arrangement of particular working conditions. The 


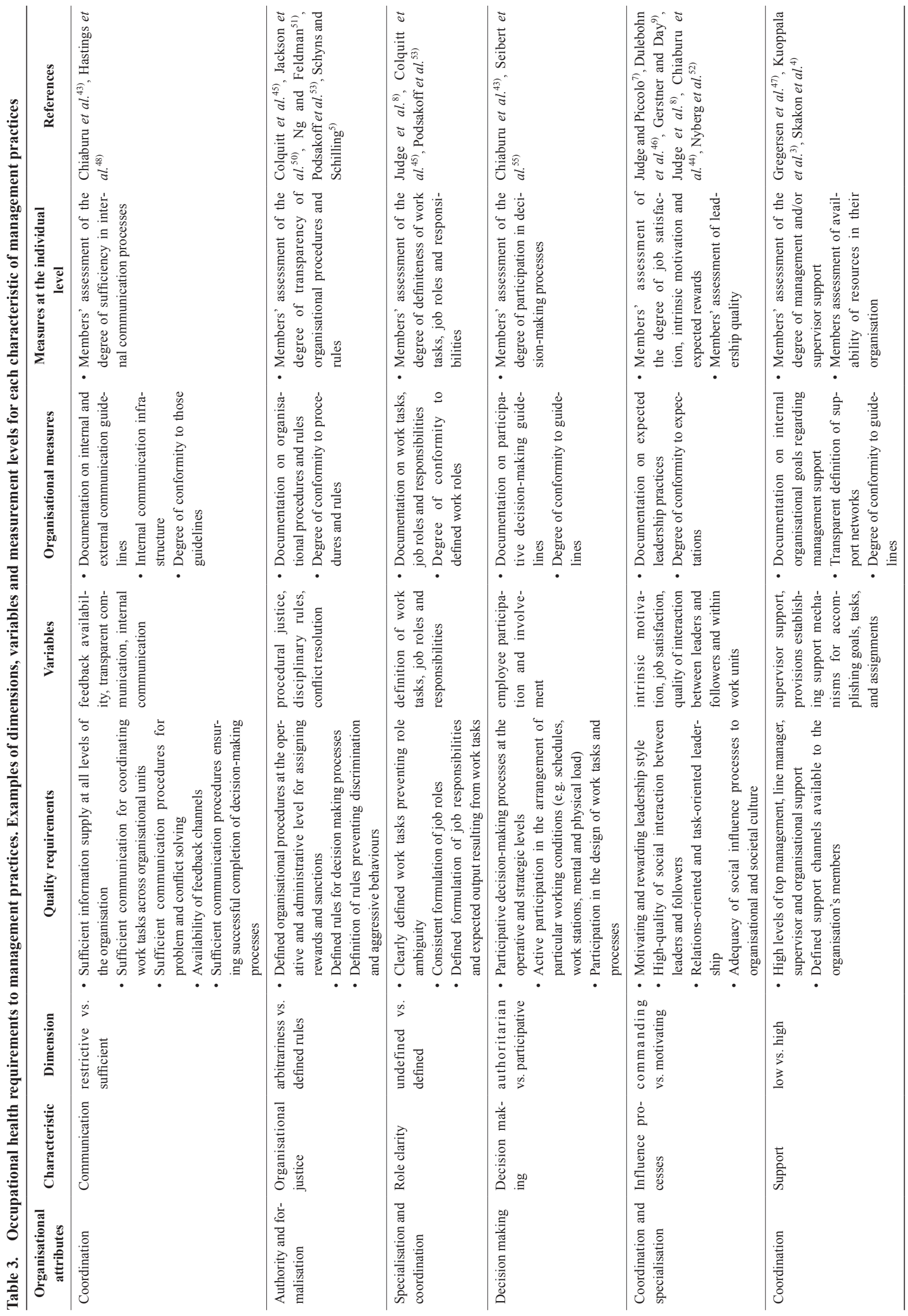


corresponding quality requirement to management practices consists of the availability of participation channels and procedures concerning the particular work processes, tasks and conditions affecting the individual members of the organisation. Social influence processes take place at the leader-follower and leader-team level and involve typical leadership phenomena such as motivational, emotional, and social exchange processes. High-quality management practices are thus characterised among others by the enactment of motivating and inspiring leadership, excellent quality of social interaction and exchange between leaders and followers, and the adequacy of the leadership behaviours and styles to the specific organisational and societal culture. Support encompasses not only social support received from top and line managers and supervisors, but also the support channels institutionalised in organisational procedures. The quality requirements to management practices of support are therefore based on high levels of (social) support, availability of support channels, and clearly defined support networks.

\section{ISO 9000-based Quality Management of Man- agement Practices}

\section{Continual improvement of management practices}

Conformity to occupational health requirements regarding management practices can be appropriately achieved by concatenating all quality management processes related to products and services with the quality of management practices as depicted schematically in Fig. 1. Conformity to the requirements of customers and other interested parties regarding organisational products and services is thus related indirectly to the fulfilment of occupational health requirements, in so far as they serve as inputs to the organisational processes resulting in a certain quality of output (see Fig. 1).

The standardisation approach of management practices depicted in Fig. 1 is not only a formal representation of relationships between different system components, it also illustrates causal relationships. For instance, the needs or expectations of customers or other interested parties distally cause how and to which extent resources are needed, the particular design of work processes leading to the realisation of products, and the amount of organisational output (upper quality loop in Fig. 1). At the same time, they may also determine to some extent how management practices are enacted, the degree to which management resources are used, and consequently the health states of the organisation's members (lower quality loop in Fig. 1). On a similar argument, overall organisational output and a high quality of products and services depend on how healthy the members of the organisation are.

The incorporation of quality requirements for management practices in the organisational processes reinforces the feedback mechanisms of the ISO 9000 system. This is done by taking into account not only the information supplied by customers and other interested parties, but also internally by the organisation's members. Hence, as a feedback system operating at two levels, the standardisation of management practices in continual improvement processes contributes to the design of more precise systems from imprecise components and to stabilise the system against external disturbances ${ }^{22}$.

\section{Improving the management practices of organisations}

Within the conceptual framework of ISO 9001:2008 it is possible to specify the sub-processes depicted in Fig. 1, and to formulate core activities for the improvement and effectiveness of management practices ${ }^{37}$.

Management's responsibility. Top management shall commit itself to the development and implementation of the quality management system of management practices by taking into account the health-related requirements of the organisation's members. In addition, top management should establish the quality policy of management practices, conduct management reviews and quality controls, and ensure the availability of resources for accomplishing the quality policy objectives. These activities should be performed in compliance with the occupational health requirements established in Table 3 for management practices, and, at the same time, guarantee the fulfilment of all organisational functions (see Fig. 1).

Resource management. The organisation should provide all resources needed for the implementation and maintenance of high-quality management practices. This includes hiring managers and supervisors with appropriate management practices skills, and providing adequate training for the fulfilment of high-quality management practices. The effectiveness of management practices in relation to occupational health requirements and the health states of the organisation's members should be regularly evaluated. Importantly, it should be ensured that the personnel are aware of the relevance and importance of their activities toward high-quality management practices.

Management practices realisation. The organisation shall plan and develop processes for the realisation of high-quality management practices. This includes the definition of quality objectives, the integration of management practices in organisational processes, and the selection 
Table 4. Illustration of the assessment of communication practices on the basis of the auditing guidelines of ISO 19011:2011

\begin{tabular}{|c|c|c|c|}
\hline \multicolumn{4}{|c|}{ Communication practices audit } \\
\hline Criteria & Evidence & Findings & Conclusions \\
\hline $\begin{array}{l}\text { - Sufficient information sup- } \\
\text { ply at all levels of the organ- } \\
\text { isation } \\
\text { - Sufficient communication } \\
\text { for coordinating work tasks } \\
\text { across organisational units } \\
\text { - Sufficient communication } \\
\text { procedures for problem and } \\
\text { conflict solving } \\
\text { - Availability of feedback } \\
\text { channels } \\
\text { - Sufficient communication } \\
\text { procedures ensuring suc- } \\
\text { cessful completion of deci- } \\
\text { sion-making processes }\end{array}$ & $\begin{array}{l}\text { - Organisational-level measures (e.g. communica- } \\
\text { tion procedures and channels) } \\
\text { - Individual-level measures (e.g. self-reported } \\
\text { measures of amount of information received and } \\
\text { sent, expectations concerning information sup- } \\
\text { ply, timeliness, and satisfaction with communi- } \\
\text { cation processes) } \\
\text { - Instruments (e.g. Communication Audit of the } \\
\text { International Communication Association }{ }^{56)} \text { ) } \\
\text { - Methodology of data collection and analysis: } \\
\text { O Qualitative (e.g. interviews, observation; criti- } \\
\text { cal incident analysis, content analysis) } \\
\text { Quantitative (e.g. questionnaires, email traffic; } \\
\text { statistical analysis) }\end{array}$ & $\begin{array}{l}\text { Evaluation of conformity } \\
\text { vs. non-conformity of evi- } \\
\text { dence with audit criteria } \\
\text { - If applicable, grading of the } \\
\text { extent of conformity and } \\
\text { non-conformity, respec- } \\
\text { tively }\end{array}$ & $\begin{array}{l}\text { - Review of audit findings and } \\
\text { health-related issues in the } \\
\text { organisation } \\
\text { - Preparation of recommenda- } \\
\text { tions } \\
\text { - Evaluation of the extent of } \\
\text { conformity with the audit cri- } \\
\text { teria } \\
\text { - Evaluation of effectiveness, } \\
\text { good practices, and weak- } \\
\text { nesses } \\
\text { - Identification of causes of } \\
\text { findings } \\
\text { - Preparation of recommenda- } \\
\text { tions for continual improve- } \\
\text { ment }\end{array}$ \\
\hline
\end{tabular}

of specific monitoring and measurement criteria. These processes should ensure that the health requirements of the organisation's members are being fulfilled. Furthermore, inputs and outputs of management practices shall be evaluated to assess whether they meet occupational health requirements and to identify and solve problems hindering the implementation of high-quality management practices.

Measurement, analysis and improvement. The organisation shall be responsible for implementing appropriate measurement, analysis and improvement processes required to demonstrate conformity to occupational health requirements. In addition, these processes should enhance the continual improvement of high-quality management practices. Internal and external audits of management practices shall be regularly performed according to appropriate evaluation methods. Measurement of health indicators related to physical and mental health of the organisation's members should be used to inform the development and improvement of organisational quality policy on a regular basis.

\section{Assessing the quality of management practices}

The assessment of quality management practices may follow general auditing procedures as represented in international standards such as ISO 19011:2011 ${ }^{38)}$. For instance, the quality requirements summarised in Table 3 may be used as audit criteria against which evidence collected at the organisational and individual level is compared. An analysis of conformity between the audit criteria and the collected evidence may be then used to derive specific conclusions and recommendations regarding the effectiveness, robustness and continual improvement of the management practices. As an illustration, a general procedure for assess- ing the quality of communication is reproduced in Table 4 (see Quinn \& Hargie ${ }^{39)}$ and Hargie, Tourish \& Wilson ${ }^{40)}$ for selected case studies).

\section{Discussion}

The main objective of the present study was to propose a standardisation approach which combines the results obtained in occupational health research on management (and leadership) practices, and the commitment demanded from management to attain organisational goals. To this end, an ISO-9000 standardisation approach was adopted, and six major occupational health requirements to highquality management practices comprising communication processes, organisational justice, role clarity, decision making, social influence processes and support were described. There are at least three major advantages of this ISO-9000 standardisation approach. First, this approach is fully compatible with international quality management standards. Second, a process-oriented quality system should be capable of ensuring the continual improvement of occupational safety and health standards by considering the structural causes of work-related hazards and/or diseases. And third, current auditing procedures such as the ISO 19011:2011 may be easily adapted or extended in order to include the evaluation of the quality of management practices in organisations ${ }^{38)}$.

Nonetheless, several limitations ought to be mentioned. First, the present standardisation approach does not claim to comprise all imaginable occupational health requirements to management practices. In order to establish a set of minimum requirements, it was necessary to reduce the 
number and complexity of requirements at the cost of an extensive catalogue of occupational health requirements. For instance, the proposed approach does not formulate cultural specificity as an independent requirement, although it has been recognised that cultures and organisations within countries may differ substantially regarding central facets of management and/or leadership such as charismatic leadership, team-oriented and participative leadership ${ }^{41)}$. However, the requirements to management practices reported in Table 3 are general enough as to allow the adaptation of particular components to the expected requirements of organisation's members in different cultural and sectorial settings. For instance, despite the fact that an autocratic or dictatorial leadership style is commonly sanctioned in several cultures around the globe, there is cross-cultural variation regarding the value (and practice) of employee participation in decision-making processes ${ }^{41,42}$. Although a higher level of participation seems to be desirable in most cultures, the optimal degree of participation within a specific cultural and organisational setting may be lower in absolute terms, as long as the health requirements of the organisation's members are met.

Second, since the present standardisation approach assumes that organisations have already implemented a quality management system based on continual improvement processes, the expected number of organisations willing to implement the standardisation of management practices is limited. Third, the definition of dimensions of measurement for each organisational characteristic reported in Table 3 is not exhaustive. In fact, future studies should evaluate and confirm the practicability, validity and predictive power of the dimensions proposed in the present study. It will be also necessary to assess the extent to which both the proposed variables and the organisational and individual measures capture the core features of highquality management practices.

\section{Conclusions}

Management practices designate the overt and measurable behaviours, and institutionalised norms such as instructions, prescriptions, proscriptions and sanctions enacted by the leading members of the organisation that enable the coordination of activities to direct and control an organisation. In terms of modern occupational health regulations and guidelines, the quality of these practices may be improved by developing a quality management system of management practices that ensures not only conformity to product but also to occupational safety and health requirements. Future research should evaluate in practical settings the practicability, effects, benefits and drawbacks of the standardisation approach proposed in this study.

\section{References}

1) Yukl G (2013) Leadership in organizations. Pearson, Essex.

2) ISO 9000 (2005) Quality management systems - Fundamentals and vocabulary. Beuth Verlag, Berlin.

3) Kuoppala J, Lamminpää A, Liira J, Vainio H (2008) Leadership, job well-being, and health effects - a systematic review and a meta-analysis. J Occup Environ Med 50, 904 15 (doi:10.1097/JOM.0b013e31817e918d). [Medline] [CrossRef]

4) Skakon J, Nielsen K, Borg V, Guzman J (2010) Are leaders' well-being, behaviours and style associated with the affective well-being of their employees? A systematic review of three decades of research. Work Stress 24, 107-39 (doi:10. 1080/02678373.2010.495262). [CrossRef]

5) Schyns B, Schilling J (2013) How bad are the effects of bad leaders? A meta-analysis of destructive leadership and its outcomes. Leadersh Q 24, 138-58 (doi:10.1016/j. leaqua.2012.09.001). [CrossRef]

6) Lang J, Ochsmann E, Kraus T, Lang JWB (2012) Psychosocial work stressors as antecedents of musculoskeletal problems: a systematic review and meta-analysis of stabilityadjusted longitudinal studies. Soc Sci Med 75, 1163-74 (doi:10.1016/j.socscimed.2012.04.015). [Medline] [CrossRef]

7) Judge TA, Piccolo RF (2004) Transformational and transactional leadership: a meta-analytic test of their relative validity. J Appl Psychol 89, 755-68 (doi:10.1037/0021-9010. 89.5.755). [Medline] [CrossRef]

8) Judge TA, Piccolo RF, Ilies R (2004) The forgotten ones? The validity of consideration and initiating structure in leadership research. J Appl Psychol 89, 36-51 (doi: 10.1037/0021-9010.89.1.36). [Medline] [CrossRef]

9) Gerstner C, Day D (1997) Meta-analytic review of LeaderMember Exchange theory: Correlates and construct issues. J Appl Psychol 82, 827-44 (doi:10.1037/0021-9010. 82.6.827). [CrossRef]

10) Mathieu JE, Zajac DM (1990) A review and meta-analysis of the antecedents, correlates, and consequences of organizational commitment. Psychol Bull 108, 171-94 (doi: 10.1037/0033-2909.108.2.171). [CrossRef]

11) Mintzberg H (1973) The nature of managerial work. Harper \& Row, New York.

12) Fleishman EA, Mumford MD, Zaccaro SJ, Levin KY, Korotkin AL, Hein MB (1991) Taxonomic efforts in the description of leader behavior: A synthesis and functional interpretation. Leadersh Q 2, 245-87 (doi:10.1016/10489843(91)90016-U). [CrossRef]

13) Tengblad S (ed) (2012) The Work of Managers: Towards a Practice Theory of Management. Oxford University Press, Oxford. (doi:10.1093/acprof:oso/9780199639724.001.0001) 
[CrossRef]

14) Bass BM, Bass R (2008) The Bass handbook of leadership. 4 edn. Free Press, New York.

15) Boxall P, Purcell J, Wright PM (eds) (2009) The Oxford Handbook of Human Resource Management. Oxford University Press, Oxford. (doi:10.1093/oxfordhb/ 9780199547029.001.0001). [CrossRef]

16) Halbesleben JRB, Leroy H, Dierynck B, Simons T, Savage GT, McCaughey D, Leon MR (2013) Living up to safety values in health care: the effect of leader behavioral integrity on occupational safety. J Occup Health Psychol 18, 395-405 (doi:10.1037/a0034086). [Medline] [CrossRef]

17) Franke F, Felfe J, Pundt A (2014) The impact of health-oriented leadership on follower health development and test of a new instrument measuring health-promoting leadership. Zeitschrift für Personalforschung 28, 139-61 (doi:10.1688/ ZfP-2014-01-Franke). [CrossRef]

18) NICE (2015) Workplace health: management practices. NICE Guideline (NG13). National Institute for Health and Care Excellence (NICE), London.

19) ILO (2001) Guidelines on occupational safety and health management systems, ILO-OSH 2001. International Labour Office, Geneva.

20) Walters D, Wadsworth E, Quinlan M (2013) Analysis of the determinants of workplace occupational safety and health practice in a selection of EU Member States. European Agency for Safety and Health at Work (EU-OSHA), Luxembourg.

21) Halperin WE (1996) The role of surveillance in the hierarchy of prevention. Am J Ind Med 29, 321-3 (doi:10.1002/ (SICI)1097-0274(199604)29:4<321::AID-AJIM8> 3.0.CO;2-R). [Medline] [CrossRef]

22) Aström K, Murray R (2008) Feedback systems. Princeton University Press, Princeton.

23) House R, Hanges P, Javidan M, Dorfman P, Gupta V (eds) (2004) Culture, leadership, and organizations : the GLOBE study of 62 societies. Sage Publication, Thousand Oaks.

24) Kashima Y, Laham SM, Dix J, Levis B, Wong D, Wheeler $M$ (2015) Social transmission of cultural practices and implicit attitudes. Organ Behav Hum Decis Process 129, 113-25 (doi:10.1016/j.obhdp.2014.05.005). [CrossRef]

25) Kuhnert KW, Lewis P (1987) Transactional and transformational leadership: A constructive/developmental analysis. Acad Manage Rev 12, 648-57 (doi:10.5465/amr.1987. 4306717). [CrossRef]

26) Bass BM (1985) Leadership: Good, better, best. Organ Dyn 13, 26-40 (doi:10.1016/0090-2616(85)90028-2). [CrossRef]

27) Graen GB, Uhl-Bien M (1995) Relationship-based approach to leadership: Development of leader-member exchange (LMX) theory of leadership over 25 years: Applying a multi-level multi-domain perspective. Leadersh Q 6, 219 47 (doi:10.1016/1048-9843(95)90036-5). [CrossRef]

28) Karasek R, Theorell T (1990) Healthy work: stress, productivity, and the reconstruction of working life. Basic Books, New York.
29) Rhoades L, Eisenberger R (2002) Perceived organizational support: a review of the literature. J Appl Psychol 87, 698714 (doi:10.1037/0021-9010.87.4.698). [Medline] [CrossRef]

30) Kieser A, Walgenbach P (2010) Organisation. 6 edn. Schäffer-Poeschel Verlag, Stuttgart.

31) Bedeian A (1980) Organizations: theory and analysis. The Dryden Press, Hinsdale.

32) Greenberg J (1990) Organizational Justice: Yesterday, Today, and Tomorrow. J Manage 16, 399-432 (doi:10.1177/ 014920639001600208). [CrossRef]

33) Cropanzano R, Byrne ZS, Bobocel DR, Rupp DE (2001) Moral Virtues, Fairness Heuristics, Social Entities, and Other Denizens of Organizational Justice. J Vocat Behav 58, 164-209 (doi:10.1006/jvbe.2001.1791). [CrossRef]

34) Jackson SE, Schuler RS (1985) A meta-analysis and conceptual critique of research on role ambiguity and role conflict in work settings. Organ Behav Hum Decis Process 36, 16-78 (doi:10.1016/0749-5978(85)90020-2). [CrossRef]

35) Tubre TC, Collins JM (2000) Jackson and schuler (1985) revisited: a meta-analysis of the relationships between role ambiguity, role conflict, and job performance1. J Manage 26, 155-69 (doi:10.1016/S0149-2063(99)00035-5). [CrossRef]

36) King LA, King DW (1990) Role conflict and role ambiguity: A critical assessment of construct validity. Psychol Bull 107, 48-64 (doi:10.1037/0033-2909.107.1.48). [CrossRef]

37) ISO 9001 (2008) Quality management systems - Requirements. Beuth Verlag, Berlin.

38) ISO 19011 (2011) Guidelines for auditing management systems. Beuth Verlag, Berlin.

39) Dennis Q, Owen H (2004) Internal communication audits: a case study. Corporate Communications: An International Journal 9, 146-58 (doi:10.1108/13563280410534348). [CrossRef]

40) Hargie O, Tourish D, Wilson N (2002) Communication Audits and the Effects of Increased Information: A Followup Study. J Bus Commun 39, 414-36 (doi:10.1177/002194 360203900402). [CrossRef]

41) Dorfman P, Hanges P, Brodbeck F (2004) Leadership and cultural variation. In: House R, Hanges P, Javidan M, Dorfman P, Gupta V (eds) Culture, leadership, and organizations: the GLOBE study of 62 societies. Sage Publications, Thousand Oaks, 669-719.

42) Dorfman P, Javidan M, Hanges P, Dastmalchian A, House R (2012) GLOBE: A twenty year journey into the intriguing world of culture and leadership. J World Bus 47, 504-18 (doi:10.1016/j.jwb.2012.01.004). [CrossRef]

43) Chiaburu DS, Lorinkova NM, Van Dyne L (2013) Employees' Social Context and Change-Oriented Citizenship: A Meta-Analysis of Leader, Coworker, and Organizational Influences. Group Organ Manage 38, 291-333 (doi:10.1177/1059601113476736). [CrossRef]

44) Chiaburu DS, Smith TA, Wang J, Zimmerman RD (2014) Relative importance of leader influences for subordinates' proactive behaviors, prosocial behaviors, and task perfor- 
mance: A meta-analysis. J Pers Psychol 13, 70-86 (doi:10.1027/1866-5888/a000105). [CrossRef]

45) Colquitt JA, Scott BA, Rodell JB, Long DM, Zapata CP, Conlon DE, Wesson MJ (2013) Justice at the millennium, a decade later: a meta-analytic test of social exchange and affect-based perspectives. J Appl Psychol 98, 199-236 (doi:10.1037/a0031757). [Medline] [CrossRef]

46) Dulebohn JH, Bommer WH, Liden RC, Brouer RL, Ferris GR (2012) A Meta-Analysis of Antecedents and Consequences of Leader-Member Exchange: Integrating the Past With an Eye Toward the Future. J Manage 38, 1715-59 (doi:10.1177/0149206311415280). [CrossRef]

47) Gregersen S, Kuhnert S, Zimber A, Nienhaus A (2011) Führungsverhalten und Gesundheit - Zum Stand der Forschung. [Leadership behaviour and health - current research state]. Gesundheitswesen 73, 3-12 (doi:10.1055/s-0029-1246180). [Medline] [CrossRef]

48) Hastings SE, Armitage GD, Mallinson S, Jackson K, Suter E (2014) Exploring the relationship between governance mechanisms in healthcare and health workforce outcomes: A systematic review. BMC Health Serv Res 14, 479 (doi:10.1186/1472-6963-14-479). [Medline] [CrossRef]

49) Ilies R, Nahrgang JD, Morgeson FP (2007) Leader-member exchange and citizenship behaviors: a meta-analysis. J Appl Psychol 92, 269-77 (doi:10.1037/0021-9010.92.1.269). [Medline] [CrossRef]

50) Jackson EM, Rossi ME, Hoover ER, Johnson RE (2012) Relationships of leader reward behavior with employee behavior: Fairness and morale as key mediators. Leadersh Organ Dev J 33, 646-61 (doi:10.1108/01437731211265232). [CrossRef]

51) Ng TWH, Feldman DC (2014) Ethical Leadership: MetaAnalytic Evidence of Criterion-Related and Incremental Validity. J Appl Psychol (doi:10.1037/a0038246). [Medline] [CrossRef]

52) Nyberg A, Bernin P, Theorell T (2005) The impact of leadership on the health of subordinates vol 1. National Institute for Working Life, Stockholm. http://www.su.se/polopoly_ fs/1.51750.1321891474!/P2456_AN.pdf.

53) Podsakoff PM, Bommer WH, Podsakoff NP, MacKenzie SB (2006) Relationships between leader reward and punishment behavior and subordinate attitudes, perceptions, and behaviors: A meta-analytic review of existing and new research. Organ Behav Hum Decis Process 99, 113-42 (doi:10.1016/j.obhdp.2005.09.002). [CrossRef]

54) Rockstuhl T, Dulebohn JH, Ang S, Shore LM (2012) Leadermember exchange (LMX) and culture: a meta-analysis of correlates of LMX across 23 countries. J Appl Psychol 97, 1097-130 (doi:10.1037/a0029978). [Medline] [CrossRef]

55) Seibert SE, Wang G, Courtright SH (2011) Antecedents and consequences of psychological and team empowerment in organizations: a meta-analytic review. J Appl Psychol 96, 981-1003 (doi:10.1037/a0022676). [Medline] [CrossRef]

56) Goldhaber G, Rogrs D (1979) Auditing organizational communication systems: The ICA Communication Audit.
Kendall-Hunt, Dubuque.

\section{Annex 1}

Scopus $(n=98)$

(title-abs-key(leadership) OR title-abs-key(leader member exchange) OR title-abs-key(transformational leadership) OR title-abs-key(leader behavior)) AND (titleabs-key(performance) OR title-abs-key(satisfaction) OR title-abs-key(citizenship) OR title-abs-key(turnover) OR title-abs-key(productivity) OR title-abs-key(wellbeing) OR title-abs-key(job satisfaction) OR title-abskey(affect) OR title-abs-key(depression) OR title-abskey(musculoskeletal)) AND (title-abs-key(organization) OR title-abs-key(employee)) AND (title-abs-key(metaanalysis) OR title-abs-key(systematic-review))

\section{PsycArticles $(\mathrm{n}=12)$}

(leadership OR leader member exchange OR transformational leadership OR leader behavior) AND (performance OR satisfaction OR citizenship OR turnover OR productivity OR well-being OR job satisfaction OR affect OR depression OR musculoskeletal) AND (organization OR employee) AND (meta-analysis OR systematic-review)

\section{PubMed $(\mathrm{n}=38)$}

("leadership"[All Fields] OR "leader member exchange"[All Fields] OR "transformational leadership"[All Fields] OR "leader behavior"[All Fields]) AND ("performance"[All Fields] OR "satisfaction"[All Fields] OR “citizenship"[All Fields] OR “turnover"[All Fields] OR "productivity”[All Fields] OR “well-being”[All Fields] OR "job satisfaction"[All Fields] OR "affect*"[All Fields] OR "depress*"[All Fields] OR "musculoskeletal"[All Fields]) AND ("organization"[All Fields] OR "employee*"[All Fields]) AND ("meta-analysis"[Title/Abstract] OR "systematic review"[Title/Abstract])

The systematic search was amended by manual search in the following journals: Academy of Management Journal, American Journal of Industrial Medicine, European Journal of Work, Applied Psychology: An International Review, European Journal of Work and Organizational Psychology, Human Relations, The International Journal of Human Resource Management, Journal of Applied Psychology, Journal of Occupational Health Psychology, Journal of Occupational and Organizational Psychology, Journal of Organizational Behavior, Journal of Vocational Behavior, and Work \& Stress. 